Izvirni znanstveni članek / Original scientific article

\title{
Ogroženost za padce v terciarni bolnišnici
}

Risk for falls in a tertiary care hospital

\author{
Maja Klančnik Gruden
}

Ključne besede: padci;
dejavniki tveganja; Morsejina
lestvica padcev; akutna
zdravstvena oskrba; varnostni
zaplet

Key words: falls; risk factors; Morse Falls Scale; acute care; safety incident

asist. mag. Maja Klančnik Gruden, viš. med. ses., prof. zdr. vzg.; Univerzitetni klinični center Ljubljana, Zaloška cesta 2, 1000 Ljubljana, Slovenija, in Univerza v Mariboru, Fakulteta za zdravstvene vede, Žitna ulica 15, 2000 Maribor, Slovenija

Kontaktni e-naslov / Correspondence e-mail: maja.klancnik@kclj.si

\section{IZVLEČEK}

Uvod: Namen raziskave je bil ugotoviti, kakšna je ogroženost za padce odraslih pacientov v akutni zdravstveni obravnavi ter kakšne so razlike v ogroženosti glede na spol, starost, kraj pacientove obravnave (kliniko) in specialnost stroke ter kategorijo zahtevnosti bolnišnične zdravstvene nege.

Metode: Uporabljeno je bilo kvantitativno raziskovanje - presečna opazovalna raziskava. Vzorec $(n=1361)$ je vključeval odrasle paciente, hospitalizirane v Univerzitetnem kliničnem centru Ljubljana. Podatki so se zbirali na za to posebej razvitem instrumentu, pri čemer je bila ogroženost za padce vrednotena z Morsejino lestvico. Podatki so se zbirali od oktobra do novembra 2015. Poleg osnovne deskriptivne statistike so bili uporabljeni tudi Mann-Whitneyjev test, test ANOVA in Pearsonov korelacijski test.

Rezultati: Raziskava je pokazala, da je v akutni zdravstveni obravnavi v slovenski terciarni bolnišnici zmerno do visoko ogroženih za padce $69,1 \%(n=940)$ pacientov, od tega je $28,0 \%(n=381)$ visoko ogroženih. Ogroženost pacientov za padce je pozitivno povezana s starostjo $(r=0,462, \mathrm{p}<0,001)$. Razlikuje se tudi glede na kliniko $(F=29,210, p<0,001)$, specialnost stroke $(Z=-5,660, \mathrm{p}<0,001)$ ter kategorijo zahtevnosti zdravstvene nege $(F=125,464, p<0,001)$.

Diskusija in zaključek: Pomembno bolj ogroženi so starejši, pacienti, razvrščeni v višje kategorije zahtevnosti bolnišnične zdravstvene nege, ter pacienti, zdravljeni v okviru internističnih strok. Rutinsko ocenjevanje ogroženosti, načrtovanje in izvajanje ukrepov za preprečevanje padcev so temelji zmanjševanja padcev.

\section{ABSTRACT}

Introduction: The purpose of the study was to determine the risk for falls in adult patients in acute care setting and differences in risk between groups with respect to gender, age, clinical setting (clinic) and medical specialty, as well as the category of nursing care complexity.

Methods: A quantitative study - a cross-sectional observational study was used. Adult patients hospitalized in University Medical Centre Ljubljana were included in the sample $(n=1,361)$. The instrument was developed for collecting data, where the risk for falls was evaluated with the Morse Fall Scale. The data were collected from October to November 2015. In addition to basic descriptive statistics, the Mann-Whitney test, the ANOVA test and Pearson correlation test were also used.

Results: The study showed that in acute care given in a Slovenian tertiary hospital, $69.1 \%(n=940)$ of patients were at moderate to severe risk for falls, of which $28.0 \%(n=381)$ were at severe risk. The risk for falls was positively related to age $(r=0.462, p<0.001)$. It also differed according to department $(F=29.210, p<$ $0.001)$, according to the medicine specialty $(Z=-5.660, p<0.001)$ and according to the category of nursing complexity of care $(F=125.464, p<0.001)$.

Discussion and conclusion: Older people, people in higher categories of nursing care complexity and medical units' patients have a significantly higher risk for falls than others. Routine assessment of risk for falls, planning and implementation of falls prevention measures are the basis for reducing falls. 


\section{Uvod}

Padci so eden najpogostejših varnostnih zapletov $\mathrm{v}$ bolnišnicah (Callis, 2016), predvsem med starejšo populacijo (Berry \& Kiel, 2017), ter so najpogosteje razlog za izgubo samostojnosti (Kiel, 2016) in nižjo kakovost življenja starejših (Tidy, 2016). Raziskave kažejo, da se število padcev $\mathrm{v}$ akutni zdravstveni obravnavi giblje med 3 in 5 na 1000 bolnišnično oskrbnih dni (Zhao \& Kim, 2015), v slovenskih splošnih bolnišnicah med 1,1 in 1,7 na 1000 bolnišnično oskrbnih dni (UKC Ljubljana, 2014). Večina padcev se konča brez manjših posledic ali z njimi, medtem ko se $5 \%$ padcev v bolnišnicah konča s težkimi poškodbami (Kiel, 2016). Burns in sodelavci (2016) so ugotovili, da so bili v letu 2015 v Združenih državah Amerike stroški zdravljenja pacientov, ki umrejo za posledicami padca, 637,5 milijona USD, pacientov, ki so se zdravili zaradi padca in preživeli, pa 31,3 bilijona USD ter da se stroški nenehno povečujejo.

Ocenjevanje pacientov glede ogroženosti za padce je primarna intervencija preprečevanja padcev (Callis, 2016). Sardo in sodelavci (2016) so na podlagi Morsejine lestvice ogroženosti za padce ugotovili, da je več kot polovica $(54,2 \%)$ hospitaliziranih odraslih pacientov $\mathrm{v}$ splošni bolnišnici na Portugalskem zmerno do visoko ogroženih za padce ter da so bolj ogroženi za padce starejši, ženske, urgentno sprejeti in pacienti $\mathrm{z}$ daljšo ležalno dobo. Klančnik-Gruden in sodelavci (2017) so analizirali ogroženost za padce pri pacientih $\mathrm{z}$ internističnimi obolenji. Za oceno ogroženosti so uporabili Morsejino lestvico padcev in ugotovili, da je bilo zmerno do visoko ogroženih $76 \%$ pacientov $\mathrm{z}$ internističnimi obolenji ter da so bile bolj ogrožene za padce ženske, pacienti, hospitalizirani na oddelku za žilne bolezni, in pacienti z obolenji dihal ter infekcijskimi in drugimi parazitskimi boleznimi po Mednarodni klasifikaciji bolezni (MKB-10).

V literaturi se omenjajo različni dejavniki tveganja za padce. Callis (2016) je identificirala sledeče dejavnike tveganja za padec v bolnišnici: spremembe v izločanju, depresija, rakavo obolenje, vrtoglavica, motnje ravnotežja/mišična oslabelost, anamnestični podatek o padcu v preteklosti, moški spol, uporaba zdravil, kot so antidepresivi, antidiabetiki, antiepileptiki, antiparkinsoniki, antipsihotiki, benzodiazipini, zdravila za srce, diuretiki, hipnotiki, statini, opioidi/ narkotiki, polifarmacija (štiri zdravila ali več). Zhao in Kim (2015) navajata še starost in podaljšano trajanje hospitalizacije; Tidy (2016) ženski spol, nizko težo, odvisnost pri vsakdanjih aktivnostih, zlorabo alkohola, sladkorno bolezen, motnje vida in okoljske dejavnike; Herdman in Kamitsuru (2017) pa še samsko življenje in akuten izbruh bolezni.

$\mathrm{Za}$ oceno ogroženosti hospitaliziranih pacientov za padce poznamo različne lestvice: Morsejino lestvico padcev, model Hendrich II, St. Thomasovo lestvico (Callis, 2016), Schmidovo lestvico za oceno ogroženosti za padec in John Hopkinsovo bolnišnično lestvico za oceno ogroženosti za padec (Berry \& Kiel, 2016).

Morsejino lestvico padcev je razvila Janice Morse $s$ sodelavci. Njena uporaba je hitra in enostavna. Ima šest meril, relativno visoko senzitivnost (78 \%) in specifičnost (83 \%) (Morse, et al., 1989) oz. točnost napovedi tveganja za padec. Nekateri avtorji sicer ugotavljajo, da ni pomembne razlike med klinično presojo izkušene medicinske sestre in oceno, pridobljeno na podlagi standardizirane ocenjevalne lestvice (Berry \& Kiel, 2016), vendar ocenjevalna lestvica poleg pomoči medicinski sestri pri ocenjevanju ogroženosti deluje tudi kot opomnik (Klančnik-Gruden, et al., 2017). Rutinsko ocenjevanje ogroženosti v vnaprej določenih intervalih pa je ena od najbolj pomembnih intervencij za preprečevanje padcev (Kiel, 2016), ki je v domeni medicinskih sester.

\section{Namen in cilji}

Raziskava je bila izvedena $\mathrm{z}$ namenom (1) preučiti ogroženost za padce odraslih pacientov $\mathrm{v}$ akutni zdravstveni obravnavi ter (2) raziskati razlike $\mathrm{v}$ ogroženosti za padec glede na spol, starost, kraj pacientove obravnave (kliniko) in specialnost stroke ter kategorijo zahtevnosti zdravstvene nege.

Cilj raziskave je bil ugotoviti, kakšna je ogroženost za padce odraslih pacientov $\mathrm{v}$ akutni zdravstveni obravnavi ter če se ogroženost razlikuje glede na spol, starost, kraj pacientove obravnave (kliniko) in specialnost stroke (kirurške vs. internistične) ter kategorijo zahtevnosti bolnišnične zdravstvene nege.

Raziskovalne hipoteze so bile naslednje:

H1: Ogroženost odraslih pacientov za padce v akutni zdravstveni obravnavi se pomembno razlikuje glede na spol pacientov.

H2: Ogroženost odraslih pacientov za padce v akutni zdravstveni obravnavi se pomembno razlikuje glede na starost pacientov.

H3: Ogroženost odraslih pacientov za padce v akutni zdravstveni obravnavi se pomembno razlikuje glede na kliniko, na kateri so pacienti hospitalizirani.

H4: Ogroženost odraslih pacientov za padce v akutni zdravstveni obravnavi se pomembno razlikuje glede na specialnost stroke.

H4: Ogroženost odraslih pacientov za padce v akutni zdravstveni obravnavi se pomembno razlikuje glede na kategorijo zahtevnosti zdravstvene nege pacientov.

\section{Metode}

$\mathrm{V}$ raziskavi je bila uporabljena kvantitativna metodologija - presečna opazovalna raziskava, ki je potekala v okviru projekta »Ogroženost za padce v Univerzitetnem kliničnem centru (UKC) Ljubljana«. 


\section{Opis instrumenta}

Za zbiranje podatkov je bil razvit delno strukturiran vprašalnik, sestavljen iz dveh delov. $\mathrm{V}$ prvem delu so bila vprašanja o oddelku (klinika, število postelj, število zaposlenih), $\mathrm{v}$ drugem delu pa podatki o pacientu (demografski podatki, kategorija zahtevnosti zdravstvene nege, medicinske diagnoze po skupinah primerljivih primerov, zdravila, ocena ogroženosti za padce po Morsejini lestvici padcev, izvedeni preventivni ukrepi). Vprašanja so bila zaprtega in pol odprtega tipa. Razumljivost instrumenta je bila testirana na enem oddelku pri dveh pacientih. Medicinski sestri, ki sta testirali instrument, sta ga ocenili kot razumljivega in enostavnega za uporabo. Zanesljivost in veljavnost instrumenta nista bili izmerjeni.

$S$ pomočjo Morsejine lestvice padcev preverjamo pri pacientih šest kategorij dejavnikov tveganja (padec $\mathrm{v}$ zadnjih treh mesecih, spremljajoče medicinske diagnoze, uporabo pripomočkov oz. potrebo po pomoči pri gibanju, žilni in / ali drug pristop, način hoje, duševno stanje), od katerih so uporaba pripomočkov oz. potreba po pomoči pri gibanju, način hoje in duševno stanje razdeljeni $\mathrm{v}$ podkategorije. $\mathrm{Na}$ podlagi seštevka točk $(\mathrm{Min}=0$, Maks $=125)$ se paciente razvrsti v tri stopnje ogroženosti: nizka (0-24 točk), zmerna (25-50 točk) in visoka (51 točk in več). Pri analizi smo prisotnost podkategorij zanemarili ter primerjali med seboj samo glavne kategorije.

V slovenski bolnišnični zdravstveni negi za namen kvantificiranja in prikazovanja potreb po zdravstveni negi uporabljamo metodo slovenske kategorizacije zahtevnosti bolnišnične zdravstvene nege (KlančnikGruden, et al.,2011), kijebila razvita na podlagi metode San Joaquin. Na podlagi enajstih meril se paciente razvrsti $\mathrm{v}$ štiri kategorije zahtevnosti zdravstvene nege. Pri tem je prva kategorija najmanj (pretežno samostojni pacienti), četrta (popolnoma odvisni in vitalno ogroženi pacienti) pa najbolj zahtevna.

Starostne skupine, opisane v članku, so bile delno povzete po opredelitvi profesorja Alessandra Rosinija (Caltabiano, et al., 2017), ki glede na današnji življenjski slog definira devet starostnih skupin: otroci (0-15 let), mladi (16-24 let), mladi odrasli (25-34 let), odrasli (35-54 let), starejši odrasli (55-64 let), mlajši starejši (65-74 let), starejši (75-84 let) in starejši stari (> 85 let). Za namen članka je izpuščena starostna skupina otroci, združeni pa sta starostni skupini mladi in mladi odrasli.

\section{Opis vzorca}

Vzorec je vseboval odrasle paciente, hospitalizirane v UKC Ljubljana, na dan izvajanja raziskave stare 16 let ali več, ki so bili v času izvajanja raziskave prisotni na oddelku. V raziskavo je bilo vključenih 1361 pacientov (štirje pacienti so bili mlajši od 16 let; 108 pacientov je bilo na dan raziskave odsotnih $\mathrm{z}$ oddelka zaradi preiskav ali posegov). UKC Ljubljana je razdeljen na enajst klinik, kjer se zdravijo odrasli. Povprečna starost pacientov, zajetih $\mathrm{v}$ vzorec, je bila 62,75 let $(s=18,68)$, delež moških vvzorcu je bil 49,7 \%. Največji delež vzorca so predstavljali pacienti, hospitalizirani na Kirurški $(n=425,31,2 \%)$ in Interni kliniki $(n=418,30,7 \%)$. Preostali vzorec so predstavljali pacienti Ginekološke klinike, Nevrološke klinike, Klinike za infekcijske bolezni in vročinska stanja, Ortopedske klinike, Klinike za otorinolaringologijo in maksilofacialno kirurgijo, Očesne klinike, Negovalnega oddelka, Klinike za nuklearno medicino in Dermatovenerološke klinike (Tabela 4).

Pacienti v vzorcu so bili razporejeni v vse štiri kategorije zahtevnosti zdravstvene nege. Največ jih je bilo v drugi $(n=539,40,5 \%)$ in tretji kategoriji $(n=457,34,3 \%)$, manj pa $\mathrm{v}$ prvi $(n=271,20,3 \%)$ in najmanj v četrti kategoriji $(n=65,4,9 \%)$ (Tabela 6).

\section{Opis poteka raziskave in obdelave podatkov}

Raziskava je bila odobrena s strani Strokovnega sveta UKC Ljubljana. Potekala je v obdobju od 12. oktobra 2015 do 12. novembra 2015. Vsi pacienti na eni enoti so bili pregledani na isti dan med sedmo in petnajsto uro. Predstavitev poteka raziskave in instrumenta za zbiranje podatkov je bila podana glavnim medicinskim sestram klinik, navodila za izvedbo raziskave pa medicinskim sestram za kakovost na ravni klinik, ki so skupaj z medicinskimi sestrami na ravni kliničnih oddelkov zbirale podatke na dan raziskave. Podatki o pacientih so se zbirali $\mathrm{v}$ anonimizirani obliki na papirnatih obrazcih. Medicinske sestre na ravni klinike so zbrane podatke združile ter jih poslale vodstvu zdravstvene nege UKC Ljubljana, kjer jih je za vse klinike zbrala raziskovalka.

Zbrani podatki so bili obdelani s statističnim programom SPSS, verzija 24 (SPSS Inc,. Chicago, IL, USA). Za ugotavljanje razlik v ogroženosti za padce na podlagi Morsejine lestvice padcev med spoloma in med specialnostmi strok (kirurška vs. internistična stroka) je bil uporabljen Mann-Whitneyjev test, za ugotavljanje razlik v ogroženosti za padce na podlagi Morsejine lestvice padcev med klinikami ter med kategorijami zahtevnosti bolnišnične zdravstvene nege test ANOVA, za ugotavljanje povezanosti med starostnimi skupinami in ogroženostjo za padce na podlagi Morsejine lestvice padcev pa Pearsonov korelacijski test. Pri vseh testih je bila upoštevana meja statistične zanesljivosti $(p<0,05)$.

\section{Rezultati}

Pri ocenjevanju ogroženosti za padce po Morsejini lestvici je bilo največ pacientov zmerno ogroženih $(41,1 \%)$, delež nizko ogroženih $(30,9 \%)$ je bil malo večji od deleža visoko ogroženih pacientov $(28,0 \%)$. Zmerno in visoko ogroženih je bilo skupaj 69,1\% pacientov (Tabela 1). 
Tabela 1: Ogroženost odraslih pacientov za padce po Morsejini lestvici padcev

Table 1: Risk for falls in adult patients according to Morse Fall Scale

\begin{tabular}{lll}
\hline Stopnja ogroženosti / Risk level & $\boldsymbol{n}$ & \% \\
\hline Nizka ogroženost (0-24) & 421 & 30,9 \\
Zmerna ogroženost (25-50) & 559 & 41,1 \\
Visoka ogroženost (51-125) & 381 & 28,0 \\
Skupaj & 1361 & 100,0 \\
\hline Dejavniki tveganja / Risk factors & $\boldsymbol{n}$ & $\mathbf{\%}$ \\
\hline Padec v zadnjih treh mesecih & 203 & 6,8 \\
Sekundarna medicinska diagnoza & 1040 & 34,9 \\
Pripomočki/pomoč pri gibanju & 388 & 13,0 \\
Žilni in/ali drug pristop & 788 & 26,5 \\
Hoja (slabotna ali motena) & 415 & 13,9 \\
Duševno stanje & 144 & 4,9 \\
\hline Skupaj & $2978^{\star}$ & 100,0 \\
\hline
\end{tabular}

Legenda / Legend: $n$ - stevilo / number; \% - odstotek / percentage; * - skupno število dejavnikov tveganja je večje od števila pacientov, ker je imel lahko en pacient istočasno več dejavnikov tveganja / total number of risk factors is greater than the number of patients, as one patient could suffer from several risk factors at the same time
Najpogosteje prisotna dejavnika tveganja sta bila: sekundarna medicinska diagnoza $(n=1040,34,9 \%)$ in žilni in / ali drug pristop $(n=788,26,5 \%)$. Sledila sta: hoja (slabotna ali motena) $(n=415,13,9 \%)$ in uporaba pripomočkov / pomoči za gibanje $(n=388,13,0 \%)$. Najredkeje pa sta bila prisotna dejavnika: padec $\mathrm{v}$ zadnjih treh mesecih $(n=203,6,8 \%)$ in motnje $\mathrm{v}$ duševnem stanju $(n=144,4,9 \%)$ (Tabela 1$)$.

Analiza podatkov po spolu je s pomočjo MannWhitneyjevega testa pokazala, da med spoloma ni razlike v ogroženosti za padce $(Z=-0,933, p=0,351)$, kar nam pokaže tudi prekrivanje mej 95-\% intervalov zaupanja posameznih skupin (Tabela 2).

Tabela 3 prikazuje razliko med starostnimi skupinami, ki je še posebej razvidna v intervalih zaupanja. S pomočjo Pearsonovega korelacijskega testa smo primerjali podatke o ogroženosti in starosti (Tabela 3 ) ter ugotovili, da so statistično pomembno pozitivno povezani $(r=$ $0,462, p<0,001)$, kar pomeni, da se ogroženost za padce sorazmerno povečuje s starostjo (Slika 1 ).

Tabela 2: Ogroženost za padce glede na spol po Morsejini lestvici padcev

Table 2: Risk for falls and gender according to Morse Fall Scale

\begin{tabular}{lllllllll}
\hline $\begin{array}{l}\text { Spol / } \\
\text { Gender }\end{array}$ & $\boldsymbol{n}(\%)$ & $\overline{\boldsymbol{X}}$ & $\begin{array}{l}\mathbf{9 5 \%} \mathbf{I Z} / \\
\mathbf{9 5 \%} \boldsymbol{C I}\end{array}$ & Min & Maks & $\boldsymbol{s}$ & $\boldsymbol{Z}$ & $\boldsymbol{p}$ \\
\hline Moški & $670(49,7)$ & 39,65 & $37,81-41,49$ & 0 & 125 & 24,280 & $/$ & $/$ \\
\hline Ženski & $679(50,3)$ & 38,76 & $36,84-40,68$ & 0 & 125 & 25,461 & $/$ & $/$ \\
\hline Skupaj & $1349(100)$ & 39,20 & $37,87-40,53$ & 0 & 125 & 24,876 & $-0,933$ & 0,351 \\
\hline Brez podatka & 12 & $/$ & $/$ & $/$ & $/$ & $/$ & $/$ & $/$ \\
\hline
\end{tabular}

Legenda / Legend: $n$ - število / number; \% - odstotek / percentage; $\bar{x}$ - povprečje / average; IZ / CI - interval zaupanja / confidence interval; Min - minimum / minimum; Maks - maksimum / maximum; s - standardni odklon / standard deviation; $Z$ - MannWhitneyjev test / Mann-Whitney test; $p$ - statistična značilnost / statistical significance

Tabela 3: Ogroženost za padce glede na starost po Morsejini lestvici padcev

Table 3: Risk for falls and age according to Morse Fall Scale

\begin{tabular}{|c|c|c|c|c|c|c|c|c|}
\hline $\begin{array}{l}\text { Starostne skupine / } \\
\text { Age groups }\end{array}$ & $n(\%)$ & $\bar{X}$ & $\begin{array}{l}95 \% I Z / \\
95 \% C I\end{array}$ & Min & Maks & $s$ & $r$ & $p$ \\
\hline $\begin{array}{l}\text { Mladi } \\
(16-34)\end{array}$ & $150(11,3)$ & 20,04 & $17,61-23,19$ & 0 & 75 & 17,267 & I & I \\
\hline $\begin{array}{l}\text { Odrasli } \\
(35-54)\end{array}$ & $237(17,9)$ & 28,29 & $25,58-31,00$ & 0 & 90 & 21,161 & 1 & 1 \\
\hline $\begin{array}{l}\text { Starejši odrasli } \\
(55-64)\end{array}$ & $235(17,7)$ & 33,64 & $30,92-36,36$ & 0 & 105 & 21,139 & 1 & 1 \\
\hline $\begin{array}{l}\text { Mlajši stari } \\
(65-74)\end{array}$ & $267(20,1)$ & 43,88 & $41,09-46,66$ & 0 & 110 & 23,138 & I & l \\
\hline $\begin{array}{l}\text { Stari } \\
(75-84)\end{array}$ & $320(24,1)$ & 49,56 & $46,85-52,27$ & 0 & 125 & 24,638 & I & l \\
\hline $\begin{array}{l}\text { Starejši stari } \\
(>85)\end{array}$ & $119(8,9)$ & 57,14 & $53,19-61,10$ & 15 & 125 & 21,800 & I & I \\
\hline Skupaj & $1328(100)$ & 39,19 & $37,86-40,52$ & 0 & 125 & 24,764 & 0,462 & $<0,001$ \\
\hline Brez podatka & 33 & I & 1 & 1 & 1 & 1 & I & 1 \\
\hline
\end{tabular}

Legenda / Legend: $n$ - število / number; \% - odstotek / percentage; $\bar{x}$ - povprečje / average; IZ / CI - interval zaupanja / confidence interval; Min - minimum / minimum; Maks - maksimum / maximum; $s$ - standardni odklon / standard deviation; $r$ - Pearsonov korelacijski koeficient / Pearson correlation coefficient; p-statistična značilnost / statistical significance 


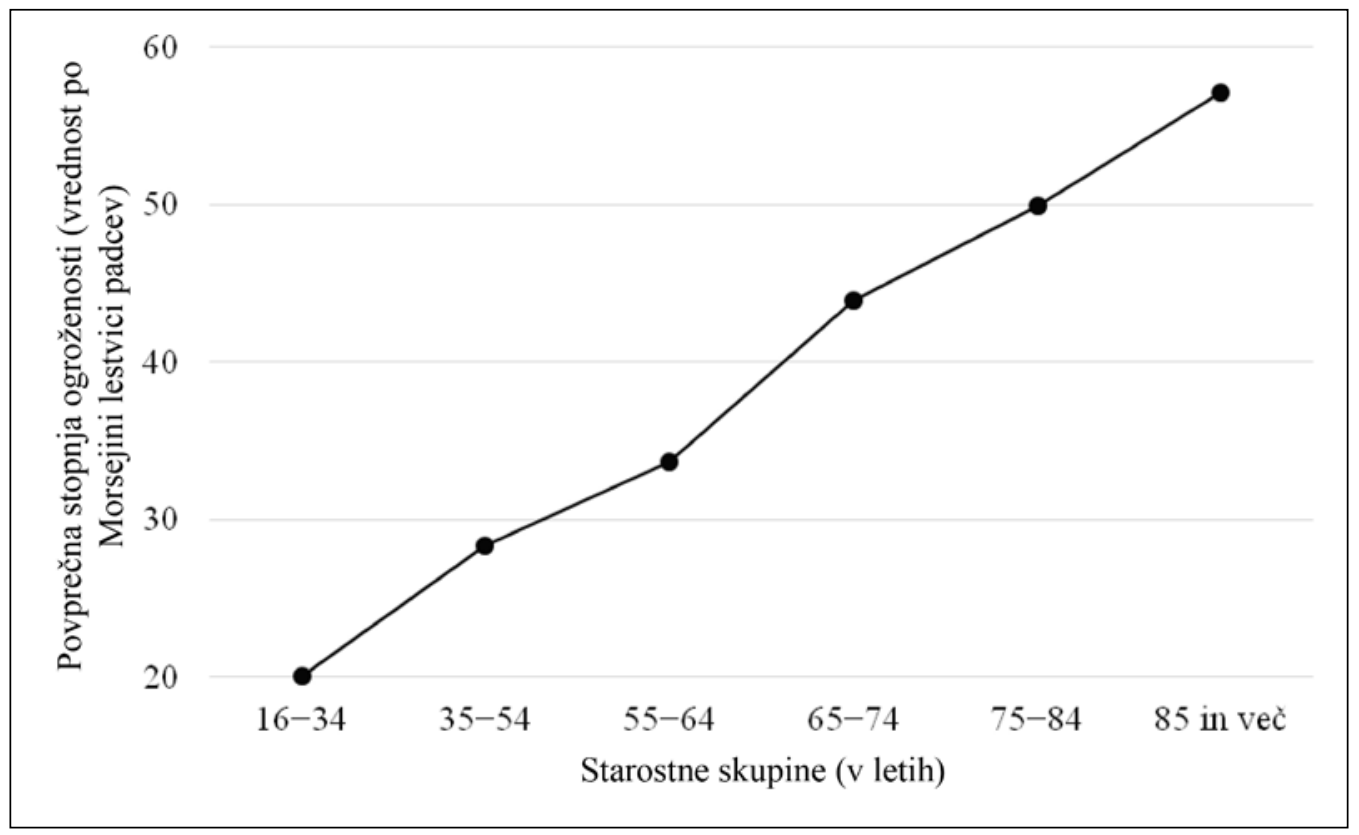

Slika 1: Povezanost med ogroženostjo za padce in starostjo pacientov

Figure 1: Correlation between risk for falls and age

Analiza podatkov s pomočjo testa ANOVA je pokazala, da se ogroženost pacientov za padce med krajem pacientove obravnave statistično pomembno razlikuje $(F=29,210, p<0,001)$. Pacienti, hospitalizirani na Negovalnem oddelku, Interni kliniki in Kirurški kliniki, so $\mathrm{v}$ povprečju statistično pomembno bolj ogroženi od povprečne ogroženosti vseh pacientov, medtem ko so pacienti, hospitalizirani na Ginekološki kliniki, Očesni kliniki, Dermatovenerološki kliniki, Kliniki za nuklearno medicino ter na Kliniki za otorinolaringologijo in cervikofacialno kirurgijo, $\mathrm{v}$ povprečju statistično pomembno manj ogroženi od povprečne ogroženosti vseh pacientov, kar nam kažejo podatki o intervalih zaupanja (Tabela 4). Ogroženost za padce pacientov, hospitaliziranih na Negovalnem oddelku, močno odstopa od vseh ostalih klinik. Poleg tega so razlike v ogroženosti pacientov na tem oddelku podpovprečne $(s=16,782, \mathrm{Min}=30$, Maks $=105)$. Večjo enotnost v ogroženosti pacientov za padce lahko razberemo na Ginekološki, Očesni ter Kliniki za infekcijske bolezni in

Tabela 4: Ogroženost za padce po Morsejini lestvici padcev in kraj pacientove obravnave Table 4: Risk for falls according to Morse Fall Scale and department

\begin{tabular}{|c|c|c|c|c|c|c|c|c|}
\hline Klinika / Clinic & $n(\%)$ & $\bar{x}$ & $\begin{array}{l}95 \% \text { IZ / } \\
95 \% \text { CI }\end{array}$ & Min & Maks & $s$ & $F$ & $p$ \\
\hline Ginekološka & $140(10,3)$ & 16,89 & $14,13-19,66$ & 0 & 85 & 16,561 & 1 & 1 \\
\hline Očesna & $38(2,8)$ & 22,11 & $16,38-27,83$ & 0 & 65 & 17,423 & 1 & 1 \\
\hline Dermatovenerološka & $19(1,1)$ & 22,63 & $12,62-32,64$ & 0 & 65 & 20,774 & 1 & 1 \\
\hline KNM & $11(1,1)$ & 28,18 & $14,98-41,39$ & 0 & 65 & 19,656 & 1 & 1 \\
\hline ORL & $40(2,9)$ & 27,75 & $19,59-35,91$ & 0 & 100 & 25,519 & 1 & 1 \\
\hline Ortopedska & $69(5,1)$ & 33,91 & $28,49-39,34$ & 0 & 75 & 22,588 & 1 & 1 \\
\hline Nevrološka & $95(7,0)$ & 36,89 & $31,79-42,00$ & 0 & 125 & 25,066 & 1 & 1 \\
\hline KIBVS & $77(5,7)$ & 42,47 & $38,48-46,46$ & 15 & 85 & 17,577 & 1 & 1 \\
\hline Kirurška & $425(31,2)$ & 43,24 & $41,09-45,38$ & 0 & 110 & 22,470 & 1 & 1 \\
\hline Interna & $418(30,7)$ & 44,37 & $41,94-46,79$ & 0 & 125 & 25,200 & 1 & 1 \\
\hline Negovalni oddelek & $29(2,1)$ & 74,31 & $67,93-80,69$ & 30 & 105 & 16,782 & 1 & 1 \\
\hline Skupaj & $1361(100)$ & 39,12 & $37,80-40,44$ & 0 & 125 & 24,853 & 29,210 & $<0,001$ \\
\hline
\end{tabular}

Legenda / Legend: $n$ - število / number; \% - odstotek / percentage; $\bar{x}$ - povprečje / average; IZ / CI - interval zaupanja / confidence interval; Min - minimum / minimum; Maks - maksimum / maximum; $s$ - standardni odklon / standard deviation; F- test ANOVA / ANOVA test; p -statistična značilnost / statistical significance; KIBVS - Klinika za infekcijske bolezni in vročinska stanja / Department of Infectious Diseases; ORL - Klinika za otorinolaringologijo in cervikofacialno kirurgijo / Department of Otorhinolaryngology and Cervicofacial Surgery; KNM - Klinika za nuklearno medicino / Department of Nuclear Medicine 
Tabela 5: Ogroženost za padce pacientov po posamezni stroki Table 5: Risk for patients' falls according to medical discipline

\begin{tabular}{lllllllll}
\hline $\begin{array}{l}\text { Medicinska stroka / } \\
\text { Medical discipline }\end{array}$ & $\boldsymbol{n ( \% )}$ & $\overline{\boldsymbol{N}}$ & $\begin{array}{l}\mathbf{9 5 \%} \boldsymbol{I Z /} \\
\mathbf{9 5 \%} \boldsymbol{C I}\end{array}$ & Min & Maks & $\boldsymbol{s}$ & $\boldsymbol{Z}$ & $\boldsymbol{p}$ \\
\hline Internistična stroka & $649(47,7)$ & 43,5 & $41,54-45,41$ & 0 & 125 & 25,147 & $/$ & $/$ \\
\hline Kirurška stroka & $712(52,3)$ & 35,15 & $33,39-36,91$ & 0 & 110 & 23,918 & $/$ & $/$ \\
\hline Skupaj & $1361(100)$ & 39,12 & $37,80-40,44$ & 0 & 125 & 24,853 & $-5,660$ & $<0,001$ \\
\hline
\end{tabular}

Legenda / Legend: $n$-število / number; \% - odstotek / percentage; $\bar{x}$ - povprečje / average; IZ / CI - interval zaupanja / confidence interval; Min - minimum / minimum; Maks - maksimum / maximum; s - standardni odklon / standard deviation; $Z$ - MannWhitneyjev test / Mann-Whitney test; p-statistična značilnost / statistical significance

Tabela 6: Ogroženost za padce in kategorija zahtevnosti bolnišnične zdravstvene nege Table 6: Risk for falls and category of nursing care complexity

\begin{tabular}{lllllllll}
\hline $\begin{array}{l}\text { Kategorija / } \\
\text { Category }\end{array}$ & $\boldsymbol{n}(\boldsymbol{\%})$ & $\overline{\boldsymbol{X}}$ & $\begin{array}{l}\mathbf{9 5 \%} \mathbf{I Z /} \\
\mathbf{9 5 \%} \boldsymbol{C I}\end{array}$ & $\boldsymbol{M i n}$ & Maks & $\boldsymbol{s}$ & $\boldsymbol{F}$ & $\boldsymbol{p}$ \\
\hline I. & $271(20,3)$ & 20,04 & $17,82-22,26$ & 0 & 110 & 18,554 & $/$ & $/$ \\
\hline II. & $539(40,5)$ & 37,23 & $35,24-39,21$ & 0 & 115 & 23,429 & $/$ & $/$ \\
\hline III. & $457(34,3)$ & 52,19 & $50,07-54,31$ & 0 & 125 & 23,066 & $/$ & $/$ \\
\hline IV. & $65(4,9)$ & 46,38 & $43,07-49,70$ & 35 & 80 & 13,361 & $/$ & $/$ \\
\hline Skupaj & $1332(100)$ & 39,31 & $37,97-40,65$ & 0 & 125 & 24,887 & 125,464 & $<0,001$ \\
\hline Brez podatka & 29 & $/$ & $/$ & $/$ & $/$ & $/$ & $/$ & $/$ \\
\hline
\end{tabular}

Legenda / Legend: $n$-število / number; \% - odstotek / percentage; $\bar{x}$ - povprečje / average; IZ / CI - interval zaupanja / confidence interval; Min - minimum / minimum; Maks - maksimum / maximum; s - standardni odklon / standard deviation; F - test ANOVA / ANOVA test; p -statistična značilnost / statistical significance

vročinska stanja. Tudi analiza podatkov o ogroženosti za padce glede na specialnost stroke (Tabela 5) je $s$ pomočjo Mann-Whitneyjevega testa pokazala statistično pomembno razliko med internistično in kirurško stroko $(Z=-5,660, p<0,001)$.

Analiza podatkov o ogroženosti za padce v povezavi $\mathrm{s}$ kategorijo zahtevnosti bolnišnične zdravstvene nege je pokazala, da obstaja statistično pomembna razlika med skupinami zahtevnosti zdravstvene nege $(F=125,464, p<0,001)$. Najbolj ogroženi za padce so pacienti v tretji kategoriji zahtevnosti, sledijo pacienti iz četrte, druge in prve kategorije. Med pacienti v četrti kategoriji zahtevnosti zdravstvene nege je najmanj razlik v ogroženosti, kar nam kažeta nizek standardni odklon in nizek rang (Tabela 6).

\section{Diskusija}

Raziskava je pokazala, da je $\mathrm{v}$ akutni zdravstveni obravnavi v slovenski terciarni bolnišnici po Morsejini lestvici padcev zmerno do visoko ogroženih za padce več kot dve tretjini odraslih hospitaliziranih pacientov, od tega je več kot četrtina pacientov visoko ogroženih. Ogroženost pacientov za padce se glede na spol ne razlikuje, razlikuje pa se glede na starost, kliniko, na kateri so bili pacienti hospitalizirani, ter glede na kategorijo zahtevnosti bolnišnične zdravstvene nege, v katero so bili razvrščeni.

Primerjava podatkov o ogroženosti pacientov za padce na podlagi Morsejine lestvice padcev v slovenski bolnišnici $(\bar{X}=39,12, s=24,85)$ s podatki portugalske splošne bolnišnice na vzorcu 8356 pacientov $(\bar{X}=30,56$, $s=22,12$ ) (Sardo, et al., 2016) je pokazala, da so bili hospitalizirani pacienti v Sloveniji bolj ogroženi. Tudi skupen delež zmerno in visoko ogroženih pacientov v portugalski bolnišnici je bil nižji (54 \%). Pri tem je treba upoštevati dejstvo, da smo primerjali podatke med terciarno in sekundarno bolnišnico.

Raziskava ni pokazala razlik $\mathrm{v}$ ogroženosti za padce med spoloma. V literaturi lahko najdemo nasprotujoče si ugotovitve glede spola. Kiel (2016), Tidy (2016) in Klančnik-Gruden in sodelavci (2017), ugotavljajo, da so ženske bolj ogrožene za padce od moških, medtem ko Callis (2016) ugotavlja, da so bolj ogroženi moški. Podatki o padcih v UKC Ljubljana kažejo, da je v letu 2016 padlo več moških (54,9\%) (Ferš, 2017). Ugotovitve glede starosti kažejo, da se ogroženost pacientov za padce s starostjo povečuje, kar potrjujejo tudi rezultati drugih avtorjev (Babine, et al., 2016; Kiel, 2016; Sardo, et al., 2016). Ugotovitve glede razlik v ogroženosti za padce na podlagi specialnosti oz. klinike, na kateri so bili pacienti hospitalizirani, kažejo razlike v ogroženosti. Bolj ogroženi so pacienti, zdravljeni na klinikah internističnih strok, kar potrjujejo tudi analize, narejene na osnovi podatkov portugalske bolnišnice (Sardo, et al., 2016). Podatki za posamezne klinike UKC Ljubljane kažejo, da so najbolj ogroženi za padce pacienti, hospitalizirani na Negovalnem oddelku, Interni kliniki in Kirurški kliniki. Zanimive so ugotovitve o ogroženosti za padce glede na kategorijo zahtevnosti zdravstvene nege. Pacienti v prvi kategoriji so bili najmanj ogroženi 
za padce, kar je bilo pričakovano, medtem ko so bili najbolj ogroženi pacienti za padce $\mathrm{v}$ tretji kategoriji zahtevnosti zdravstvene nege; pacienti $\mathrm{v}$ četrti kategoriji zahtevnosti zdravstvene nege so bili manj ogroženi kot pacienti v tretji kategoriji. Ker gre za paciente, ki so sedirani, imajo predpisano terapevtsko ležanje in se ne gibljejo, jim to $\mathrm{v}$ Morsejini lestvici padcev prinese manj točk in so dejansko manj ogroženi za padce.

Rutinska uporaba ocenjevalne lestvice za oceno ogroženosti pacientov za padce, ki vodi $\mathrm{v}$ izvajanje ustreznih ukrepov, je zelo pomemben element preprečevanja padcev na področju zdravstvene nege. Raziskava je podala podatke o ogroženosti slovenskih pacientov, hospitaliziranih $\mathrm{v}$ terciarni bolnišnici, $\mathrm{v}$ nadaljevanju pa bi bilo pomembno raziskati povezanost med ogroženostjo in dejanskimi padci pacientov ter med ogroženostjo in izvajanjem korektivnih ukrepov. Poleg tega bi bilo v prihodnje smiselno izračunati točko preloma (cut-off point) oz. mejo ogroženosti za padce za slovenski prostor, tako da bi lahko preventivne ukrepe preprečevanja padcev bolj ciljno usmerili.

Raziskava je bila izvedena kot presečna opazovalna študija, ki nam omogoča vpogled v stanje $\mathrm{v}$ nekem danem trenutku, kar je treba upoštevati pri interpretaciji in posploševanju podatkov. Morsejina lestvica padcev ima šest kategorij dejavnikov tveganja, od katerih sta dve kategoriji razdeljeni še $v$ podkategorije. Pri analizi podatkov smo jih zanemarili, saj bi bilo število enot $v$ podskupinah prenizko za izvedbo izračunov. Omejitev predstavlja tudi dejstvo, da uporabljen instrument ni bil statistično validiran.

\section{Zaključek}

Več kot dve tretjini odraslih pacientov, hospitaliziranih $\mathrm{v}$ terciarni bolnišnici, je ogroženih za padce, kar zahteva implementacijo in vzdrževanje ukrepov zdravstvene nege na področju preprečevanja padcev. Starejši, pacienti, zdravljeni na enotah internistične stroke in razvrščeni $\mathrm{v}$ višjo kategorijo zahtevnosti zdravstvene nege, so bolj ogroženi za padce. Standardizirana rutinska uporaba standardizirane lestvice pomaga ohranjati pozornost do tega področja, čeprav nekateri avtorji ugotavljajo, da ima kritična presoja medicinske sestre podobne izide ter da obstoječe lestvice niso dovolj senzitivne oz. ne pokrivajo vseh dejavnikov tveganja. $\mathrm{Z}$ uporabo standardizirane lestvice in prepoznavo drugih dejavnikov tveganja skozi ocenjevanje, postavitev negovalne diagnoze, uvedbo ustreznega načrta zdravstvene nege ter njegovo izvajanje lahko medicinske sestre pomembno pripomorejo $\mathrm{k}$ preprečevanju padcev in predvsem posledičnih poškodb ter $\mathrm{k}$ ohranjanju zdravja hospitaliziranih pacientov in zmanjševanju stroškov za zdravljenje teh poškodb. Nadaljnje raziskovanje bi bilo smotrno usmeriti v iskanje specifične meje ogroženosti za padce za slovensko populacijo hospitaliziranih pacientov (cut-off point of Morse Fall Scale), kar bi nam omogočilo oblikovanje bolj usmerjenih strategij preprečevanja padcev za paciente $\mathrm{v}$ slovenskih bolnišnicah, ki so najbolj ogroženi za padce.

\section{Zahvala / Acknowledgements}

Zahvaljujemo se medicinskim sestram in koordinatorjem za kakovost ter vsem sodelujočim, ki so sodelovali pri zbiranju podatkov, Klavdiji Peternelj, ki je v veliki meri zaslužna za izdelavo instrumenta za zbiranje podatkov, ter Ireni Košir, ki je prenesla podatke s papirnatih obrazcev v okolje Microsoft Office Excel. / We thank the nurses and the quality coordinators and others who participated in the data collection, Klavdija Peternelj, who is largely responsible for the creation of a data collection instrument, and Irena Košir, who has downloaded the data from paper forms to the Excel for Microsoft.

\section{Nasprotje interesov / Conflict of interest}

Avtorica izjavlja, da ni nasprotja interesov. / The author declairs that no conflicts of interest exist.

\section{Financiranje / Funding}

Raziskava ni bila finančno podprta. / The study received no funding.

\section{Etika raziskovanja / Ethical approval}

Raziskava je pripravljena v skladu z načeli HelsinškoTokijske deklaracije (World Medical Association, 2013) in v skladu s Kodeksom etike v zdravstveni negi in oskrbi Slovenije (2014). Raziskava je bila odobrena s strani Strokovnega sveta UKC Ljubljana (sklep 1-21/2015 z dne 6. 10. 2015). / The study was conducted in accordance with the Helsinki-Tokyo Declaration (World Medical Association, 2013) and the Code of Ethics for Nurses and Nurse Assistants of Slovenia (2014). The research was approved by the Nursing Council of UMC Ljubljana (number $1-21 / 2015,6.10 .2015)$.

\section{Literatura}

Babine, R.L., Hyrkäs, K.E., Bachand, D.A., Chapman, J.L., Fuller, V.J. \& Honess, C.A., 2016. Falls in a tertiary care hospitalassociation with delirium: a peplication study. Psychosomatics, 57(3), pp. 273-282.

https://doi.org/10.1016/j.psym.2016.01.003

PMid:27063812

Berry, S. \& Kiel, D., 2017. Falls: prevention in nursing care facilities and the hospital setting. Available at: http://www. uptodate.com/contents/falls-prevention-in-nursing-carefacilities-and-the-hospital-setting? source $=$ search result\&searc $\underline{\mathrm{h}=\text { falls }+ \text { prevention\&selectedTitle }=2 \sim 150}$ [8. 1. 2018]. 
Burns, E.R., Stevens, J.A. \& Lee, R., 2016. The direct costs of fatal and non-fatal falls among older adults - United States. Journal of Safety Research, 58, pp. 99-103.

https://doi.org/10.1016/j.jsr.2016.05.001

PMid:27620939

Callis, N., 2016. Falls prevention: identification of predictive fall risk factors. Applied Nursing Research, 29, pp. 53-58.

https://doi.org/10.1016/j.apnr.2015.05.007

PMid:26856489

Caltabiano, M., Comolli, C.L. \& Rosina, A., 2017. The effect of the Great Recession on permanent childlessness in Italy. Demographic Research, 37(20), pp. 635-668. https://doi.org/10.4054/DemRes.2017.37.20

Ferš, S., 2017. List kazalnika: interno gradivo. Ljubljana: Univerzitetni klinični center Ljubljana, p. 10.

Haines, T.P., Hill, K., Walsh, W. \& Osborne, R., 2007. Designrelated bias in hospital fall risk screening tool predictive accuracy evaluations: systematic review and meta-analysis. Journal of Gerontology, 62(6), pp. 664-672. https://doi.org/10.1093/gerona/62.6.664

Herdman, T. H. \& Kamitsuru, S., eds., 2017. Negovalne diagnoze NANDA International: definicije in klasifikacija 2015-2017. Ljubljana: Zbornica zdravstvene in babiške nege Slovenije - Zveza strokovnih društev medicinskih sester, babic in zdravstvenih tehnikov Slovenije.

Kiel, D.P., 2016. Falls in older persons: risk factors and patient evaluation. Available at: https://www.uptodate.com/contents/ falls-in-older-persons-risk-factors-and-patient-evaluation [28. 7. 2017].

Klančnik-Gruden, M., Bregar, B., Peternelj, A. \& Marinšek, N., 2011. Slovenska kategorizacija zahtevnosti bolnišnične $z$ dravstvene nege: priročnik. Ljubljana: Zbornica zdravstvene in babiške nege Slovenije - Zveza strokovnih društev medicinskih sester, babic in zdravstvenih tehnikov Slovenije.

Klančnik-Gruden, M., Košir, I., Cotič-Anderle, M., Roš, A. \& Hvala, U., 2017. Ogroženost pacientov z internističnimi obolenji za padce. In: S. Majcen Dvoršak, T. Štemberger Kolnik, \& A. Kvas, eds. Medicinske sestre in babice - ključne za zdravstveni sistem: zbornik prispevkov $z$ recenzijo. 11. kongres zdravstvene in babiške nege Slovenije, Brdo pri Kranju, 27. in
29. november 2017. Ljubljana: Zbornica zdravstvene in babiške nege Slovenije - Zveza strokovnih društev medicinskih sester, babic in zdravstvenih tehnikov Slovenije, Nacionalni center za strokovni, karierni in osebnostni razvoj medicinskih sester in babic, pp. 445-453. Available at: https://www.zbornica-zveza. si/sites/default/files/doc attachments/kongres 90let opt.pdf [3. 1. 2018].

Kodeks etike $v$ zdravstveni negi in oskrbi Slovenije in Kodeks etike za babice Slovenije, 2014. Ljubljana: Zbornica zdravstvene in babiške nege - Zveza stroškovnih društev medicinskih sester, babic in zdravstvenih tehnikov Slovenije.

Morse, J.M., Morese, R.M. \& Tylko, S.J., 1989. Development of a scale to identify fall-prone patient. Canadian Journal on Aging, 8(4), pp. 366-377.

https://doi.org/10.1017/S0714980800008576

Sardo, P.M.G., Simoes, C.S.O., Alvarelhao, J.J.M., Simoes, J.F.F.L. \& de Melo, E.M.O.P., 2016. Fall risk assessment: retrospective analysis of Morse Fall Scale scores in Portuguese hospitalized adult patients. Applied Nursing Research, 31, pp. 34-40.

https://doi.org/10.1016/j.apnr.2015.11.013

PMid:27397816

Tidy, C., 2016. Prevention of falls in the elderly. Patient, pp. 1-10. Available at: patient.info/doctor/prevention-of-falls-inthe-elderly-pro Prevention [10. 3. 2017].

Univerzitetni klinični center Ljubljana, 2014. Priznanje Republike Slovenije za poslovno odličnost za leto 2014: javni sektor $z$ več kot 250 zaposlenimi. Ljubljana: Univerzitetni klinični center Ljubljana, p. 48.

Zhao, Y. \& Kim, H., 2015. Older adult inpatient falls in acute care hospitals: intrinsic, extrinsic, and enviromental factors. Journal of Gerontological Nursing, 41(7), pp. 29-43. https://doi.org/10.3928/00989134-20150616-05 PMid:26126026

World Medical Association, 2013. World Medical Association Declaration of Helsinki: ethical principles for medical research involving human subjects. Journal of American Medical Association, 310(20), pp. 2191-2194. https://doi.org/10.1001/jama.2013.281053

PMid:24141714 